\title{
A New Framework for Universiti Kebangsaan Malaysia Soft Skills Course: Implementation and Challenges
}

\author{
Adi-Irfan Che-Ani ${ }^{1,2}$, Khaidzir Ismail ${ }^{1}$, Azizan Ahmad ${ }^{1}$, Kadir Ariffin $^{1} \&$ Mohd Zulhanif Abd Razak ${ }^{2}$ \\ ${ }^{1}$ Pusat Citra Universiti, The National University of Malaysia, Bangi, Selangor, Malaysia \\ ${ }^{2}$ Department of Architecture, Faculty of Engineering and Built Environment, The National University of \\ Malaysia, Bangi, Selangor, Malaysia \\ Correspondence: Adi-Irfan Che-Ani, Pusat Citra Universiti, The National University of Malaysia, 43600 Bangi, \\ Selangor, Malaysia. Tel: 603-8921-5386. E-mail: adiirfan@gmail.com
}

Received: April 1, 2014 Accepted: May 9, 2014 Online Published: July 27, 2014

doi:10.5539/ies.v7n8p1 URL: http://dx.doi.org/10.5539/ies.v7n8p1

\begin{abstract}
The importance of soft skills to the graduates to compete in the working world is undeniable. Soft skills are complementary to the academic qualifications held by students. Recognizing this, the University Kebangsaan Malaysia (UKM) has established a new framework for Soft Skills courses to improve the existing framework of the course. The implementation of this course, which is started about 6 months or approximately 1 semester; is based on learning outcomes (LO) into 8 main goals. Each of these LO can be achieved by following all 8 Soft Skills courses that serve as a compulsory course in the university. These courses are conducted based on the concept of learning contracts involve an agreement between students and lecturers to determine the assignments/projects to be completed by students in a given period. Proof of learning outcomes should be uploaded by students to iFolio system that can be evaluated by evaluator (lecturers). The implementation of the new framework deals with various problems that pose challenges to both students and lecturers. There are 50 identified issues and challenges involving students, lecturers and the systems/operations. The main cause for the challenges is lack of understanding on the implementation of this course, since it is just running for its first semester. This results in a great deal of confusion which triggers the issues on the ground. However, every issue has a solution. Therefore, the management should take proactive steps as to properly deal with the issues and challenges.
\end{abstract}

Keywords: soft skills, learning contracts, new framework, challenges, UKM

\section{Introduction}

Soft skills are a major asset for graduates in working world in addition to excellent academic results. Academic excellence is simply not promising jobs as dreamed by every graduate. This is because there is intense competition among graduates for specific positions. These academic qualifications can be considered as 'tickets' to attend an interview, but soft skills are a determining factor in the success or failure in the interview session.

The challenges in the working world are fierce when workers need healthy competition to develop their careers. Excellent workers typically have better chances for promotion and earn more money. Thus, an employee must have good soft skills to be an excellent employee. For example, the leadership skills, team worker, creative and critical thinking, and wise in solving problems. These skills can be acquired by students after completed a learning contract in universities (Johnston \& Watson, 2004; Hermens \& Clarke, 2009).

Thus, the University has taken the initiative to create a course HHHC9118 - Soft Skills Development to create quality graduates who can compete in working environment. This course served as a compulsory course in the university and the requirements for graduation with a Bachelor of Honors. A study of the first group of students who have completed the course showed positive results (Che-Ani et al., 2014). The study also proved that the learning contract approach (which is incorporated into the course HHHC9118 - Soft Skill Development) able to improved soft skills among university students (Che-Ani et al., 2014). Although the course is successfully improving soft skills among the students, the University intends to make improvements by implementing a new framework that better organized than the existing framework. This paper describes the implementation and challenges for a new framework of Universiti Kebangsaan Malaysia (UKM) soft skills course. 


\section{Experiences of First Cohort}

The implementation of HHHC9118-Soft Skill Development Course for the first cohort is based on learning contract approach. Learning contract is a new approach that used as a medium for implementing and evaluating curricular activities of students at higher education institutions (HEIs) in Malaysia (Jumali et al., 2011). Learning contract means a written agreement between the students and the instructor (lecturer) to carry out the agreed tasks (Greenwood \& McCabe, 2008). In detail, the contract should contain the objective, method, period and assessment method (Neary, 2000). The students and lecturers must sign the written contract upon the agreement (Sweitzer \& King, 2008). Through this contract, students must complete the task within the stipulated time frame on their own initiative. This approach is able to develop students' knowledge and skills (Horejsi \& Garthwait, 2002). Besides, learning contract can increase the sense of responsibility among students (Lemieux, 2001) because they are directly enforcing their contract (Cross, 1996).

Before the implementation of this course, student's co-curricular activities are not assessed and duly recognized. Normally, students who participate in co-curricular activities, either in faculty or residential college just be given a certificate of appreciation by the organizers. Therefore, UKM recognized these extra-curricular activities as a core courses as a tribute to all the activities participated by the students. A total of eight credit hours allocated for Soft Skill Development courses and grades obtained by students will be recorded in the cumulative grade point average (CGPA). Thus, students who are active in extra-curricular have more potential for excellent CGPA compared with previous measurement system.

Learning Outcome (LO) obtained from student to be proven and evaluated by the assessor (lecturer/instructor) of each student. UKM provides iFolio (www.ifolio.ukm.my) applications as an avenue for students to prove all activities that participated. Proof of this can be done by uploading photos, documents, or materials that can be accessed through the website. Assessment made by the lecturer to be confirmed by Pusat Citra Universiti (previously is Centers for Learning Accreditation-CLA).

To evaluate the effectiveness of the learning contract approach in UKM, a study on the impact on the course on student was conducted. The study involved 2378 respondents who had completed the 8 credits of the course. The respondents represent 12 faculties and 12 residential colleges. A total of 10 questionnaires (statements) about students' soft skills posed to the respondents. The result shows that $84.23 \%$ of the responses were positive (Che-Ani et al., 2014).

Based on these results, it clearly demonstrates that the learning contract approach has improved the soft skills of UKM's students. This result approved the statement made by Mulder (2009) who claim that student's participation in academic and social activities will affected their achievement in university. Thus, the University has decided to pursue this course as a foundation to strengthen and develop the soft skills of the students through activities or programs. However, the University is working to enhance the filling of the course and making improvements on existing courses. The next section discusses the implementation of new Soft Skills Development course in UKM.

\section{Implementation of a New Framework for Soft Skills Development Course}

Academic curriculum is simply not complete without co-curricular activities to develop and produce graduates who are well-balanced in physical, emotional, spiritual and intellectual through life experiences in a variety of contexts and nurturing talent (PAP, 2013). Academic qualification owned by students is purely theoretical, and the activities undertaken in the learning contract is the practical of the theories. Hence, Soft Skill Development courses can bridge the gap between the theory and practice, as asserted by Rolfe (1996). Through practical based learning contract, students can improve their self-confidence, motivation, knowledge and public relations (Stewart-David, 1993). There are 8 Learning Outcomes (LO) as the main objectives of this course:

Social and accountability;

Communication skills;

Information management and lifelong learning;

Values, attitudes, ethics and professionalism;

Critical thinking, problem solving and scientific approach;

Leadership and teamwork;

Management and entrepreneurship, and

Creative and innovative. 
The new framework of soft skill development course is divided into eight new courses which are given one (1) credit hour each. The new courses are offered based on the 8 skills that become the learning outcomes and the course objectives as stated above. Students are only allowed to register a maximum of two courses per semester. All activities undertaken by the student must obtain approval from the Department of Student Services (JPPel) and can be run through a legitimate club or society registered under JPPel. Similar to the previous framework, the proof of LO obtained from the activities to be assessed by the lecturers involved. Therefore, students must upload a minimum of 3 proofs into iFolio.

iFolio stand for integrated Portfolio Management System that used as Learning Management System in UKM. All students and lecturers have an iFolio account that can be access by using valid worker's ID and students' ID. Through this system, students can access all kind of announcements, materials and information easily online. Students also can communicate with lecturers by using this system. This system will facilitate the teaching and learning proses as it can be access anywhere.

\subsection{UKM's Soft Skill Development Concept}

The implementation of the new Soft Skills Development course framework retains the same concept as the existing courses. UKM Soft Skill Development concept has eight fundamental values that should be instilled into the students such as mutual trust and honest; comprehensive learning experiences; originality; learning through experiences; fun; flexible; soft skills development, and students' self-driven. Figure 1 shows the graphical concept of UKM Soft Skills Development.

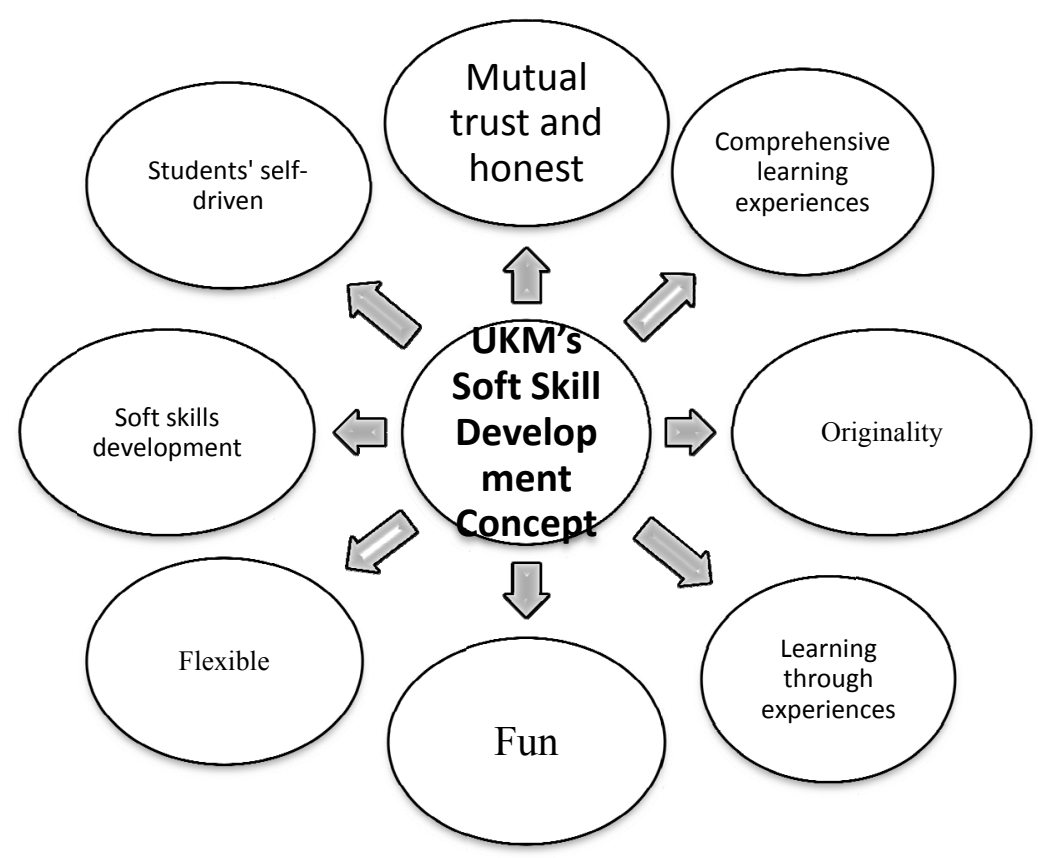

Figure 1. The concept of UKM's Soft Skill Development Courses

\section{1) Students' self-driven}

Activities selected in the learning contract must be able to encourage students' self-driven. Through the activities, students need to be more proactive and aggressive in order to complete the tasks in accordance with the goals set. This requires a variety of skills such as the skills to plan the activities, implement the activities, and problems solving. Students who have been through such activities have to be more mature and more confident of facing the working world.

2) Mutual trust and honest

Learning contract involves an agreement between students and lecturers on the activities to be undertaken by the students and will be evaluated by the lecturer. Thus, both sides must trust each other and be honest. Honesty and trust are the main pillars of the relationship between students and lecturers. In addition, the lecturers also need to ensure that the agreed contract deserves academic credit (Anderson et al., 1998) before the agreement made. 


\section{3) Comprehensive learning experiences}

Activities and programs through this learning contract to provide comprehensive learning experiences to students. All the theories learned in the classroom will be completed with practical practice. Thus, this practice will give real experience to students.

4) Learning through experiences

An experience is the best 'teacher' for everyone. Thus, the concept of soft skills is more focused on learning through experience. Experience acquired also able to distinguish the quality of graduates with equivalent academic qualifications.

\section{5) Originality}

Selected programs or activities must be original. Students and lecturers should discuss to determine the appropriate activities as learning contract that will be performed.

6) Fun

Agreed learning contract should give pleasure to the students. This is because students can choose activities according to their interests and preferences of their talents and skills. This concept can also be an impetus to students to do an activity with a vengeance without coercion. This concept coincides with Knowles (1986) who states that learning contracts give students the opportunity to do something interesting.

7) Flexible

Related activities and programs conducted in various centers of learning. Thus, there are many different learning environments. This makes the activity and the learning environment is flexible.

8) Soft skill development

Agreed learning contract should aim to acquire knowledge and soft skills. Activities that do not provide a positive impact on the soft skills of students should be avoided.

\subsection{Soft Skill Development Courses}

There are eight soft skills courses are offered based on the 8 learning outcomes. Assessment of student achievement is based on three aspects of planning (30\%), implementation $(30 \%)$ and reporting $(40 \%)$. Listed below are the courses included in the implementation of the new framework of UKM' Soft Skills Development (PAP, 2013):

\section{1) H HHC9101-Social Skills and Accountability}

The course involves an awareness individual role and responsibility to the society through the appreciation and practice of the values of community, caring and social volunteerism towards producing transformation and positive change in society. The purpose of this skill is to develop the potential and accountability through community-based programs. To complete this course, students should plan activities that can make a difference and have a positive impact on society. Activities in a flexible learning environment that enables students to interact with all levels of society, sensitive to the problems of society, take the initiative to get involved and be able to act as agents of community transformation.

\section{2) HH HC9201-Communication Skills}

The ability to speak, write and interact in a professional way and confident including in Interpersonal Communication. Communication skills also allow a person to express ideas and opinions effectively and urgently needed by a graduate in the formation of personality and career. Through participated activities, the students were exposed to communicate effectively, and apply these skills.

\section{3) HHH C9301-Information Management Skills \& Lifelong Learning}

These skills involve information management in performing its responsibilities. Strategic planning skills to master and enhance existing knowledge of the student require filtering capabilities independently in accordance with the changing information technology. Lifelong Learning is the student capable to learn new things systematically either through the learning experience formally or informally. Both of these skills are complementary. Proficiency is demonstrated by applying information management skills through the evidence materials by using appropriate software.

4) HHH C9401-Value, Attitude, Ethics \& Professionalism Skills

Values, Attitudes, Ethics and Professionalism can be built through trust, belief, and practice in performing their 
duties. This course requires students to demonstrate the efficiency, accountability, responsibility, integrity, trust and make the wise decisions affecting the economic, environmental and socio-cultural in professional practice. Students who complete this course will be a responsible person to themselves and community.

\section{5) HHH C9501-Critical Thinking, Problem Solving \& Scientific Approach Skills}

Critical thinking skills are the ability to draw conclusions about certain things based on reasonable grounds. Meanwhile, Problem solving skills is the ability to use analytical methods or the appropriate abstract with this problem. The ability to identify problems, collect data and hypothesis testing is known as Scientific Approach. The purpose of this course is to enable students to define the problem by using critical thinking and problem solving by using a scientific approach.

6) HHH C9601-Leadership \& Teamwork Skills

Leadership skill is the ability of individuals to influence others to work hard to achieve organizational goals. Teamwork skill is the ability to work in a group that works together in performing tasks to achieve team goals. These skills are very important for graduates to compete in a healthy working environment. Students enrolled in this course are able to lead themselves, groups and organizations as well as working in teams.

7) HHH C9701-Management and Entrepreneurship Skills

Planning, organizing, controlling, leading and budgets planning are included in management skills. The entrepreneurial skills included creativity, innovation, leadership, communication, confidence, resilience, competitiveness, courage, determination, problem solving, ethical, dynamic, discipline, creating ideas, taking risks, and be able to analyze opportunities. This course will help students to develop and improve the ability to manage personal and solve problems with creative and effective ideas.

\section{8) HHH C9801-Creative \& Innovative Skills}

Creative and innovative skills are important in the development of sustainable communities. Creative skills are the ability to create, produce and develop a new and original idea. Meanwhile, innovative skills are a sensitive and critical nature to environment and can improve things by using a strategy of exploration or experimentation. Students should have a creative and innovative skills with open-minded when generating ideas.

The students in these courses should reach 3 measurable domains namely confident, leadership and national identity. These domains are divided into 3 conditions such as;

1) Confident:

a) Students must have a good knowledge in the field of study;

b) Students should be well versed in their respective fields of knowledge;

c) Students should be able to use and adapt knowledge in a variety of conditions, and cultural levels; and

d) Students should have the skills to use the language of international or global work.

2) Leadership:

a) Students can communicate and interact in a team;

b) Students must have leadership and direction in terms of the functions and roles of society; and

c) Students are able to make decisions and take action based on universal values and ethics.

3) National Identity:

a) Students have a good ethic and moral values;

b) The student must have the skills and comfortable in the interaction between culture and religion;

c) Student pride and speaking the native language fluently; and

d) Students have the awareness to defend the country's sovereignty.

\section{Research Methodology}

The main objective of this research is to identify issues and problems that become the challenges to the implementation of the new framework. CLA has organized two separate workshops with lecturers and students to identify the issues and problems. Through this workshop, students and lecturers can express any views and comments on issues and problems that were encountered in the implementation of these courses. To identify the real challenges, the workshop was conducted just after the completion of the course for the first semester.

The workshop among lecturers that involved as instructors for these courses held on January, 2014 that attended 
by 40 lecturers. Then, the second workshop held on February, 2014 involving 20 student leaders. Based on these two workshops, a list of raw data that contained issues and problems were obtained. The data has tabulated and sorted, then 50 issues and problem were identified.

As for validation purposes, the third workshop with CLA's fellows were held after the issues and problems were identified. A total of 13 fellows representing all faculties in UKM involved in this workshop. These fellows verified the issues and problems that listed because they are the individuals who are directly involved with the activities of these courses and acting as a coordinator between the lecturers and students, at their respective faculty level. With their vast experience in managing these new courses (at both policy development and implementation stage), the fellows are the reliable party that can perform the validation process in identifying the issues and challenges. The issues and problem were classified into three categories such as challenge to lecturers, students and the systems/operations.

\section{Challenges in Implementing a New Framework}

The implementation of the new UKM's soft skills courses framework is not an easy task. There are many problems and issues that arise in the realization of its implementation. However, these challenges need to be faced and overcome by all the parties involved. Issues and problems can be viewed from three (3) different angles which are challenges to students, lecturers and systems/operations. Here are the challenges that have been identified.

\subsection{Challenges to Students}

Issues and problems to the students divided into three categories: prior, during and after the project.

\subsubsection{Issues and Problems for Students Prior to Project Implementation}

The following is a list of 13 issues and problems related to students prior to the implementation of the projects/activities:

a) Students are lack of understanding about the LO of courses participated.

b) There is a probability that students engaged in fraudulent of activity/strategy of LO. This is because students are free to undertake the activities and the proofing just carried out by uploading evidence into the website. Thus, there are probabilities that students get a good grade without the skills.

c) Most of the programs/projects participated by the students is arranged by others such as senior, fellows, clubs and others. Thus, the students did not act as a planner and just following the activities organized. The impact of programs/activities to produce good leaders is less effective.

d) The budget for the implementation of the LO is small (around RM200 - RM300). This limits the project to be undertaken by the students. Thus, the impacts of projects are small.

e) Most of the projects implemented in the campus and does not involve the local community. These reduce the impact of the activities.

f) Assessment method that is inconsistent with the project. The projects have been done in group, but the assessment is individually.

g) It is difficult for students to meet with lecturers. This is because there are students and lecturers that from different campuses (UKM has 3 campuses).

h) Students are still looking for a program or activity to join.

i) First Year students overloaded due to be completed $2 \mathrm{LO}$ in the 1st semester, while students are less information on those skills, and needs more time to adapt to the new environment .

j) There is confusion among students regarding project approval from the Department of Student Services (JPPel).

k) Students involved in the project that do not match with the LO registered.

1) There is a chance the student will enroll 2 course codes for a project, for example by holding two positions in a project.

m) The number of students who are evaluated for a set of increases after the expiration of the registration period. This is because some students those register after the first encounter.

\subsubsection{Issues and Problems for Students during Project Implementation}

The following is a list of 3 issues and problems related to students during the implementation of the 
projects/activities:

a) There are students involved in projects/activities that are not registered even notified by CLA.

b) There is a clash between projects' LO with educational programs in the faculty.

c) Students are unclear about the scope and other aspects to achieve LO.

5.1.3 Issues and Problems for Students after Project Implementation

The following is a list of 10 issues and problems related to students after the implementation of the projects/activities:

a) Students do not understand the methods of providing evidence for assessment purposes.

b) Students cannot be measured accurately because do not have a specific position (program committee members) though fully engaged in the program.

c) The granting of a grade less effective because of their skills is a subjective and difficult to assess.

d) The combination of the LO's programs was unsuitable.

e) Students having problems to upload the evidences of their activities.

f) There are students involved in the program implemented in Semester 1, but completed in Semester 2. This led him to be given the status of Not Complete (NC) and disrupt students to register the courses for the next semester.

g) For students with NC status, questions arise whether the assessor lecturer will still remain or change. This will be an issue if there are lecturers who have study leave or change workplace.

h) Students and assessor lecturers confused about how many LO can be proof by using evidences from one activity/program.

i) Students who don't have any video footage must produce a video from the available photos or any materials. This burdens the students to master the new skill in the same time.

j) The proper duration for the video proof is not described in detail.

\subsection{Challenges to Lecturers}

Issues and problems to the lecturers divided into three categories: prior, during and after the project.

\subsubsection{Issues and Problems for Lecturers Prior to Project Implementation}

The following is a list of 7 issues and problems related to lecturers prior to the implementation of the projects/activities:
a) Lecturers are not interested to teach/monitor students from other faculties.
b) Lecturer lack of understanding about $\mathrm{LO}$ and methods of teaching.
c) The appointment of lecturers made by faculties without their knowing.
d) Lecturers need to identify high-impact activities that can help students choose appropriate activities.
e) There are lecturers that do not conduct a meeting and could not be contacted.
f) Lecturers teaching load for the courses are not taken into account by the department/faculty.
g) Lecturers are overloaded as to provide modules or notes for students.

5.2.2 Issues and Problems for Lecturers during Project Implementation

The following is a list of 4 issues and problems related to lecturers during the implementation of the projects/activities:

a) Lecturers do not/ failed to monitor the implementation of LO by students.

b) Assessor Lecturers are required to give a lecture on LO skills that are not under their specialty/responsibility.

c) Lecturers should state the scope of work that should be produce in the form of products such as logos, posters, t-shirt design and more.

d) Difficulty in monitoring the students because students are not aware of who are their lecturers. 


\subsubsection{Issues and Problems for Lecturers after Project Implementation}

The following is a list of 3 issues and problems related to lecturers after the implementation of the projects/activities:

a) The existence of "sharing set" resulted in confusion for lecturers to assess students.

b) Lecturer lack of information on the assessment.

c) Admission student assessment scores and the scores coordination are unclear.

\subsection{Challenges to Systems/Operations}

Issues and problems to systems/operations divided into three categories: prior, during and after the project.

\subsubsection{Issues and Problems for Systems/Operations Prior to Project Implementation}

The following is a list of 7 issues and problems related to systems/operations prior to the implementation of the projects/activities:

a) Distribution of lecturers who teach LO not based on the students of the faculties.

b) Logistical problems. This is because the students and assessor lecturers are in different campuses.

c) Faculty did not cooperate for the success of LO implementation.

d) There are no specific schedules for the meeting like other academic courses.

e) Fellows are not involved in the Administration meetings and cause difficulties to raise issues related to LO.

f) The process of students' distribution to assessor lecturers was unclear.

g) Requires a special budget for discussions in groups.

5.3.2 Issues and Problems for Systems/Operations after Project Implementation

The following is a list of 3 issues and problems related to systems/operations after the implementation of the projects/activities:

a) Evaluation hods of students' achievement are unsettled.

b) iFolio system is poorly understood by most users.

c) The need to build an online FAQs on the LO.

\subsection{Discussions and Suggestions}

Based on the list, there were 50 issues and problems identified in the implementation of the new framework of UKM's Soft Skills courses. Although there are numerous issues and problems listed, the main source of the matter is the lack of understanding on the implementation of this new framework. On average, the parties involved in the course as students, assessor lecturers and instructors such as seniors and fellows are unclear on the systems and methods of implementation of the course. This cause the course cannot be implemented properly and the evaluation of students' LO is debatable.

Furthermore, the budget allocation is small causing the student activity is limited on campus only. This limited the development of soft skills for students to learn more effectively. Students should perform activities related to the community to be more exposed to the outside world. Such experience is very valuable in shaping a student who has excellent character.

For lecturers, the implementation of this course seems to give them a new load. Furthermore, the involvement of lecturers in this course seemed to not be recognized because it is outside the academic field. This situation may cause the lecturers are not interested and perform perfunctory. This may adverse impact to students' LO. The incentives and rewards system need to be properly offered to the lecturers that involved in this courses.

Therefore, the improvements should be made immediately. Immediate action to be taken is to provide a holistic and comprehensive briefing to all parties involved. So, all parties should fully understand the new framework of the courses. This briefing should be made in each residential college and faculty, so that all parties not to miss the important information. In addition, discussions between the executive and highest management should also be made so that each level of management to know the issues and problems so that they can be addressed quickly.

To facilitate the students, it is better if they are allowed to start the course in the 2 nd semester. This is because most of the new students enrolled in Semester 1 have yet to adapt to the environment and the lifestyle of the 
university. This makes it difficult for them to pursue this course well. Thus, this first semester can be used as the introduction to them so that they are more vulnerable and really understand about this course. This allows them to be better prepared and able to plan activities in advance. The introductory and compulsory modules have to be introduced to Semester 1 students so that they feel guided, before taking the Soft Skills courses.

For lecturers, courses' load as an assessor must be appreciated. Their involvement in this course should be recognized and also assessed in the KPI to ensure that each task is executed with accountability and inclusivity. In addition, CLA and faculty must cooperate so that the selection of lecturers and students performed efficiently so that communication between the two parties more efficient. This is because good communication between the two parties is a key pillar in the success of LO and transparent evaluation.

Finally, the existing system should be upgraded. Improvements in the iFolio system should be done such as provide FAQs to facilitate students and lecturers if there is confusion regarding the course. In addition, the evaluation system should also be improved because the existing system is not suitable because the grade given is like other academic courses. There are suggestions that the grade given should be "passed" and "failed" only because soft skills are something subjective to be evaluated.

\section{Conclusion}

Soft skills are the main "weapon" for graduates to face the working world full of challenges. Graduates with higher soft skills have more potential to succeed and even thrive in the working world. Thus, each institution should ensure that graduates not only have excellent academic qualification, but also have good soft skills.

The effectiveness of the learning contract approach for improving the quality of soft skills among university students was proven. This is supported by the results of research carried out on the first batch of UKM's students who have completed eight credit hours of HHHC9118-Soft Skills Development course (Che-Ani et al., 2014). Thus, the implementation of this course should continue to have a significant impact on efforts to improve the soft skills among students. However, some improvements need to be made to strengthen the modules of the course by the implementation of the new framework. However, the implementation of the new framework faces many challenges. Thus, these challenges should be overcome by taking appropriate actions based on the listed issues and problems. Since the new framework just in place of about 1 semester, CLA takes a proactive step by quickly identified all the challenges as above-mentioned. The continuous quality improvement process is easy to be planned once we have cleared ourselves with all the challenges that we are facing.

\section{References}

Anderson, G., Boud, D., \& Sampson, J. (1998). Learning Contracts. London: Kogan Page.

Che-Ani, A. I., Tawil, N. M., Johar, S., Ismail, K., \& Abd-Razak, M. Z. (2014). Universiti Kebangsaan Malaysia Learning Contract Course: Experience and Performance of the First Cohort. International Education Studies, 7(2), 1-9. http://dx.doi.org/10.5539/ies.v7n2p1

Cross, V. (1996). Introducing learning contracts into physiotherapy clinical education. Physiotherapy, 82(1), 21-27. http://dx.doi.org/10.1016/S0031-9406(05)66993-3

Greenwood, S., \& McCabe, P. (2008). How learning contracts motivate students. Middle School Journal, 39(5), 13-22.

Hermens, A., \& Clarke, E. (2009). Integrating blended teaching and learning to enhance graduate attributes. Journal of Education and Training, 51(5/6), 476-490. http://dx.doi.org/10.1108/00400910910987264

Horejsi, C. R., \& Garthwait, C. L. (2002). The social work practicum: A guide and workbook for students. Boston: Allyn \& Bacon.

Johnston, B., \& Watson, A. (2004). Participation, reflection and integration for business and lifelong learning: Pedagogical challenges of the integrative studies programme at the University of Strathclyde Business School. Journal of Workplace Learning, 16(1/2), 53-62. http://dx.doi.org/10.1108/13665620410521512

Jumali, H. S., Khaidzir, H. I., Kadaruddin, A., Kadir, A., Lukman, Z. M., Roslee, R., . . Norfadillah, D. (2011). Penilaian Aktiviti Kokurikulum Berkredit Berasaskan Kontrak Pembelajaran di UKM. Jurnal Personalia Pelajar, 14, 101-116.

Knowles, M. S. (1986). Using Learning Contracts. San Francisco, CA: Jossey Bass.

Lemieux, C. M. (2001). Learning contracts in the classroom: tools for empowerment and accountability. Journal of Social Work Education, 20(2), 263-276. http://dx.doi.org/10.1080/02615470120044347

Mulder, M., Gulikers, J., Biemans, H., \& Wesselink, R. (2009). The new competence concept in higher education: 
Error or enrichment? Journal of European Industrial Training, 33(8/9), 755-770. http://dx.doi.org/10.1108/03090590910993616

Neary, M. (2000). Teaching, Assessing and Evaluation for Clinical Competence: A Practical Guide for Practitioners and Teachers. Cheltenham: Nelson Thornes.

Pusat Akreditasi Pembelajaran (PAP). (2013). Panduan Prasiswazah Sesi Akademik 2013-2014. Bangi: Pusat Akreditasi Pembelajaran, UKM.

Rolfe, G. (1996). Closing the Theory-Practice Gap. Oxford: Butterworth Heinemann.

Stewart-David, W. (1993). Learning Contracts and Student Placements with Employers. In M. Laycock, \& J. Stephenson (Eds.), Using Learning Contracts in Higher Education (pp. 97-104). London: Routledge.

Sweitzer, H. F., \& King, M. A. (2008). The successful internship: Personal, professional, and civic development (3rd ed.). United States: Nelson Education, Ltd.

\section{Copyrights}

Copyright for this article is retained by the author(s), with first publication rights granted to the journal.

This is an open-access article distributed under the terms and conditions of the Creative Commons Attribution license (http://creativecommons.org/licenses/by/3.0/). 